\title{
THE APPLICATION OF ENVIRONMENTAL MAGNETISM TECHNIQUES FOR POLLUTION ASSESSMENT IN URBAN AND SUBURBAN AREAS IN GREECE: STATE OF THE ART AND CASE STUDIES
}

\author{
Zananiri I. ${ }^{1}$, Kondopoulou D. ${ }^{2}$ and Spassov S. ${ }^{3}$ \\ ${ }^{1}$ Institute of Geology and Mineral Exploration (I.G.M.E.), Spirou Loui 1, Olympic Village, \\ 3rd Entrance, 13677 Acharnae, Greece, izanan@igme.gr \\ ${ }^{2}$ Department of Geophysics, School of Geology, Aristotle University of Thessaloniki, \\ 54124 Thessaloniki, Greece, despi@geo.auth.gr \\ ${ }^{3}$ Centre de Physique du Globe de l'Institut Royal Météorologique de Belgique, \\ Dourbes B-5670,Belgium, simo.spassov@oma.be
}

\begin{abstract}
Environmental magnetism is a comparatively new discipline, applied in Greece only during the last decade for the study of anthropogenic pollution. The rationale of the method is based on the property of iron oxides and sulphides to attract and absorb heavy metals, organic contaminants and even radioactive pollutants. Thus, the measurement of the magnetic susceptibility, both in situ and in the laboratory, along with several other magnetic parameters constitutes a rapid and cost effective technique for characterization and mapping spatial pollution distribution. In order to quantify the correlation between magnetic susceptibility and a specific pollutant for a studied area geochemical analyses are carried out for key samples. Towards the scope of pollution assessment environmental magnetism studies have been recently carried out in the Kozani-Ptolemaida basin and the tanneries of Thessaloniki. The preliminary results of these two cases, characterized by different contaminant sources, i.e.flying ash pollution in the former and heavy metal in the latter, are presented here. In general, the application of magnetic methods proved a useful tool in the assessment of the main sources of pollution and the location of spatial distribution of major contaminants.
\end{abstract}

Key words: magnetic methods, geochemical methods, nanoparticles, environment, anthropogenic pollution.

\section{Introduction}

The major environmental problems in Greece range from air pollution, water pollution and solid waste disposal to land degradation, forest fires, threat of the natural reservations, and noise problems. However, some of these problems are of local importance and of low intensity, only. Greece has no specific clean-up legislation, unlike the United Kingdom and other European countries. Contaminated sites are treated in the general environmental protection legislation, and in the waste legislation. Up to now, there are no registers about contaminated sites, neither on a national basis nor at a regional level. Site investigations are usually isolated cases. According to an international report on waste disposal sites (Ferguson, 1999), 3500 out of 5000 facilities in Greece have been revealed to operate without any environmental protection control. 
In order to keep the living quality in urban agglomerations as high as possible, political decisions are needed which require trustable and economic scientific methods. Chemical investigations are often long-winded and expensive, thus their application is limited when the pollution degree of large areas has to be estimated. In contrast, magnetic methods offer the great advantage that low concentrations (in the order of ppm) of ferromagnetic phases can be detected, identified and quantified without costly sample preparation and within short measurement time.

\section{Philosophy of environmental magnetism for pollution assessment}

Environmental magnetism involves the application of rock and mineral magnetic techniques to situations in which the transport, deposition or transformation of magnetic grains is influenced by environmental processes in the atmosphere, hydrosphere and lithosphere (Verosub \& Roberts, 1995). An important aspect of environmental magnetism is that its techniques are relatively rapid, simple, non-destructive, inexpensive, and can be applied to a wide range of materials, including rocks, sediments, soils, atmospheric particulates and biological materials. The studies encompassed by this discipline can be divided in three major categories:

a) Regional and global climate, concerning short- and long-term estimation, through the study of lake sediments and ice cores, for the former case, and loess and deep sea sediments for the latter.

b) Anthropogenic pollution, by studying sediments (aeolian, marine, lake, rivers) and soils.

c) Biomagnetism, which concerns magnetic bacteria and human/animal tissue.

A thorough review of environmental magnetism principles and applications can be found in Evans and Heller (2003) and Walden et al. (1999).

\subsection{Heavy-metal pollution}

Motivations for controlling heavy metal concentrations are diverse (Zevenhoven \& Kilpinen, 2001), as some of them are dangerous to health or to the environment (e.g. $\mathrm{Hg}, \mathrm{Cd}, \mathrm{As}, \mathrm{Pb}, \mathrm{Cr}$ ), some may cause corrosion (e.g. $\mathrm{Zn}, \mathrm{Pb}$ ) and some are harmful in other ways (e.g. Arsenic may pollute catalysts). Within the European community the 13 elements of highest concern are $\mathrm{As}, \mathrm{Cd}, \mathrm{Co}, \mathrm{Cr}, \mathrm{Cu}, \mathrm{Hg}, \mathrm{Mn}$, $\mathrm{Ni}, \mathrm{Pb}, \mathrm{Sn}$, and $\mathrm{Tl}$, the emissions of which are regulated in waste incinerators. Some of these elements are actually necessary for humans in minute amounts $(\mathrm{Co}, \mathrm{Cu}, \mathrm{Cr}, \mathrm{Ni})$ while others are carcinogenic or toxic, affecting, among others, the central nervous system $(\mathrm{Hg}, \mathrm{Pb}, \mathrm{As})$, the kidneys or liver $(\mathrm{Hg}, \mathrm{Pb}$, $\mathrm{Cd}, \mathrm{Cu})$ or skin, bones and teeth $(\mathrm{Ni}, \mathrm{Cd}, \mathrm{Cu}, \mathrm{Cr})$.

Heavy metal pollution can arise from many sources but most commonly is due to the purification of metals, e.g., the smelting of copper and the preparation of fuels. Electroplating is the primary source of chromium and cadmium. Through precipitation of their compounds or by ion exchange into soils and muds, heavy metal pollutants can localize and lay dormant. Unlike organic pollutants, heavy metals do not decay and thus pose a different kind of challenge for remediation. Currently, plants or microrganisms are tentatively used to remove some heavy metals such as mercury. Plants which exhibit hyper accumulation can be used to remove heavy metals from soils by concentrating them in their bio matter. Some treatment of mining tailings has occurred where the vegetation is then incinerated to recover the heavy metals.

\subsection{Basic principles}

Iron is one of the most common elements in the Earth's crust. In combination with oxygen and sul- 
phur it forms magnetic minerals, which occur to a greater or lesser extent universally. Nanometre sized particles are of particular interest because they occur in great quantities, implying a large surface area. Due to these properties, nanoparticles can provoke biological reactions itself (Shukla, et al., 2000; Smith et al., 2000; Diabaté et al., 2002) or act as a vehicle for other toxic components. Iron oxides and sulfides have excellent adsorbent properties and attract not only heavy metals (Cornell and Schwertmann, 1996; Watson et al. 1995) but also organic contaminants (Apblett et al., 2001) and even radioactive pollutants (Watson et al., 2001). For obvious reasons magnetic methods can be used for the characterisation of pollution and have become commonplace by many international laboratories (e.g. Dearing et al., 1996; Petrovsky et al., 1998; Evans \& Heller, 2003; Hanesch et al., 2003).

\subsection{Magnetic minerals and pollutants}

Iron minerals in the environment result from various biogeochemical processes, such as weathering, soil formation, diagenesis of sediments and bacterial metabolism, but also human activities like fossil fuel combustion, waste incineration, metal smelting and working produce considerable amounts of iron minerals as contained in fly ashes and particulate matter (PM). Particle fractions smaller than $10 \mu \mathrm{m}$ (PM10) are of particular interest because they can be inhaled deeply into the lung and induce there cytotoxic and inflammatory effects, when iron and other heavy metals become bioavailable. Studies on fly ash highlighted that transition metals like $\mathrm{Fe}, \mathrm{Cu}, \mathrm{Ni}$ or $\mathrm{V}$ seem to play an important role (van Maanen et al. 1999). Diabaté et al. (2002) suggested that pro-inflammatory responses of cells could be induced by metals attached to the particle surface or by the large number of fine and ultrafine particles with a large surface/volume ratio. There are different source groups of PM. For instance, from the 26' 402 tons of PM10 emitted in Switzerland in 2001, $33 \%$ were allotted to industry, $25 \%$ to agriculture and forestry, $23 \%$ to road traffic and $11 \%$ to rail traffic. Household, aviation and energy production related PM10 emissions contributed only with 5,3 and $0.4 \%$, respectively (Heldstab 2002). This itemisation may be different in other countries, in particular concerning energy production in emerging markets. The largest emitters in Europe in 2000/2001 were Spain with 29'300 t, Hungary with 17'200 t and Greece and England with 14'000 t each (von Blottnitz 2006). In view of the small particles size, air suspended PM represents an enormous risk exposure for human health.

In general, particulates originating from combustion processes contain between 2 and $20 \mathrm{wt} \%$ of magnetic iron-oxides, with the highest values being observed in fly-ash resulting from coal combustion. Magnetite $\left(\mathrm{Fe}_{3} \mathrm{O}_{4}\right)$ and related spinels as well as haematite $\left(\alpha-\mathrm{Fe}_{2} \mathrm{O}_{3}\right)$ are the main magnetic minerals often found in industrial fly-ashes. They form during the burning process and are often observed in the form of spherules. Their magnetic grain size ranges from sub-micron single-domain and probably also superparamagnetic particles to large multidomain particles, probably between 2 and $50 \mu \mathrm{m}$. Fly-ashes emitted from fossil fuel burning power plants, smelting and cement factories are very rich in heavy and transition metals such as $\mathrm{As}, \mathrm{Be}, \mathrm{Co}, \mathrm{Hg}, \mathrm{Ni}$, Se.

\subsection{Measurements}

A generalized sequence of the stages followed in an environmental magnetic analysis of rock, sediment or soil samples is presented in Fig. 1.

In situ measurements of the low-field magnetic susceptibility is the primary step in every enviromagnetic study for pollution assessment (Fig. 2a). A grid is set up in dimensions depending on the nature of the survey, i.e. to study a large area measurements are taken every $500-1000 \mathrm{~m}$, while for detailed analysis of specific targets a grid of 0.5 or $1.0 \mathrm{~m}$ spacing may be required. Simultaneously, top soil samples for laboratory magnetic measurements are collected at regular intervals, using 


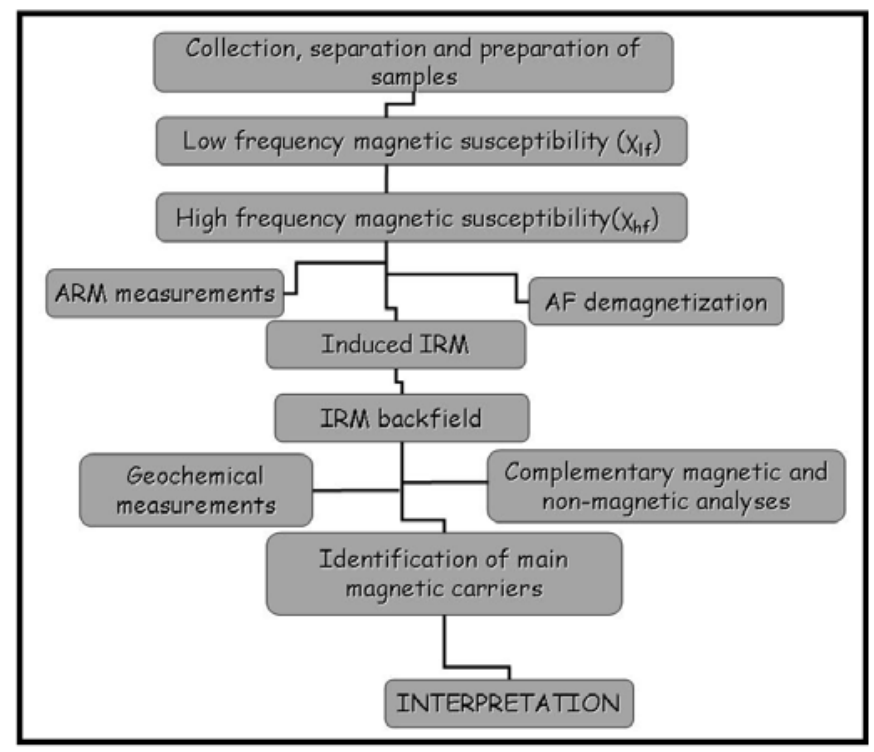

Fig. 1: Generalized sequence of stages in an environmental magnetic analysis of rock, sediment or soil samples (after Maher \& Thompson 1999).

plastic tools and bags/containers to avoid magnetic contamination. In order to reduce the biasing effect of air, water and pebbles the samples are then dried at room temperature, disaggregated and sieved, retaining the fraction smaller than $500 \mu \mathrm{m}$.

An innovative sampling technique towards the elaboration of magnetic measurements for pollution assessment involves the collection of appropriate tree-leaves, i.e. of large surface area and suitable surface properties (e.g. Acer Plantanoides). This method is based on the fact that tree-leaves, particularly those species with sticky leaves, in urban environments have a good potential to remove the atmospheric PM and, thus, can be ideal pollution monitoring markers, and has been successfully applied to many crowded cities [e.g. Beijing (Zhang et al., 2006); Zurich (Hannam \& Heller, 2001)].

In the laboratory, the low-field mass specific $(\chi)$ magnetic susceptibility is measured and percentage frequency-dependent magnetic susceptibility: , being the susceptibility measured at high frequency, usually one order of magnitude higher than $\chi_{L F}$, is calculated. Moreover, the temperature dependence of low-field magnetic susceptibility is monitored from room temperature up to $700^{\circ} \mathrm{C}$ and vice versa (Fig. 2b).

Beyond the threshold of susceptibility measurements, studies utilizing mineral magnetic properties are concerned with the measurement of magnetic characteristics affected by the concentration, grain size and shape of magnetic minerals (Table 1). These characteristics are determined by applying ar-

Table 1. Commonly measured magnetic parameters

\begin{tabular}{|l|c|c|}
\hline Magnetic Parameter & Symbol & S.I.Unit \\
\hline Mass specific susceptibility & $\chi$ & $\mathrm{m}^{3} / \mathrm{kg}$ \\
\hline Frequency dependent susceptibility & $\chi_{\mathrm{fd}}$ & $\%$ \\
\hline Isothermal remanent magnetization & $\mathrm{IRM}$ & $\mathrm{Am} / \mathrm{kg}$ \\
\hline Anhysteretic remanent magnetization & $\mathrm{ARM}$ & $\mathrm{Am} / \mathrm{kg}$ \\
\hline Susceptibility of ARM & $\chi_{\mathrm{ARM}}$ & $\mathrm{m}^{3} / \mathrm{kg}$ \\
\hline
\end{tabular}



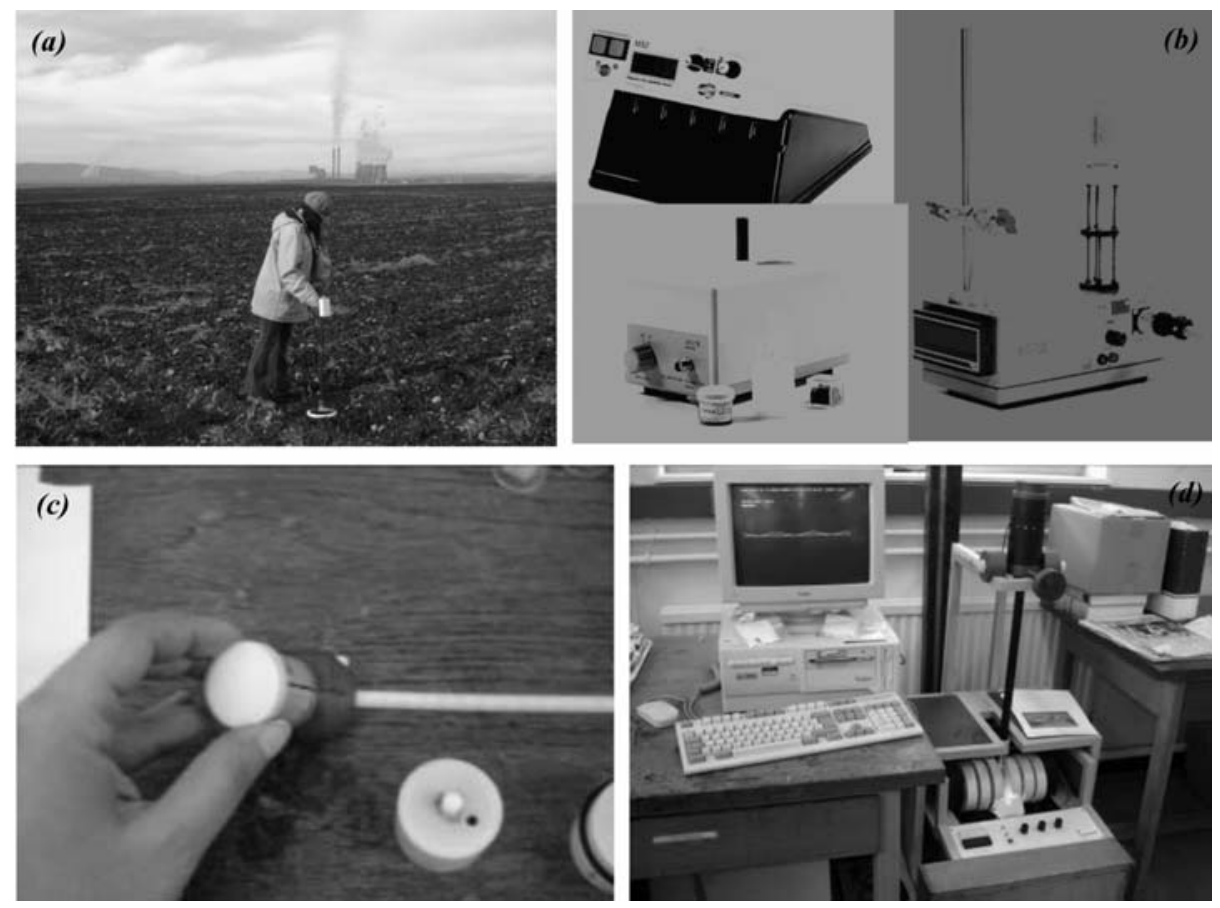

Fig. 2: (a) In situ measurement of the magnetic susceptibility, (b) Laboratory equipment (Bartington Instruments Ltd., Witney, UK) for magnetic susceptibility measurements, (c) Sample used for laboratory experiments, (d) Hysteresis loops measurement (University of Lancaster).

tificial magnetic fields and measuring either the in-field or remanent response:

- Isothermal remanent magnetisation (IRM) is induced with an impulse magnetiser, with fields reaching up to $2.7 \mathrm{~T}$, and subsequent backfield experiments are performed by subjecting the sample to the inverse magnetic field.

- Stepwise alternating field demagnetisation of both natural and isothermal remanent magnetisation.

- Hysteresis loops are measured (Fig. 2d) and the following parameters are determined: coercive force $\left(H_{c}\right)$, coercivity of remanence $\left(H_{c r}\right)$, saturation magnetization $\left(J_{s}\right)$ and saturation remanent magnetization $\left(J_{r s}\right)$.

- Anhysteretic remanent magnetization (ARM) is acquired by subjecting the sample to a DC bias field in the presence of an alternating field with decreasing peak amplitude. The ARM is expressed as a mass-specific susceptibility of ARM $\left(\chi_{\mathrm{ARM}}\right)$ by normalizing with the DC field. The ARMs are then demagnetized at successive steps (e.g. 10, 25, 50, 75, 100, 125, $150,200,250$ and $300 \mathrm{mT})$.

From the results of these experiments several diagnostic magnetic parameters are calculated, the most commonly used being: mass-normalised saturation IRM (SIRM), $\chi_{\mathrm{ARM}} / \mathrm{SIRM}$, and the percentages of high-field IRM (HIRM, i.e. the remanence acquired between 300 and $1000 \mathrm{mT}$ ). The SIRM reflects the concentration of magnetic minerals, the $\chi_{\mathrm{ARM}} / \mathrm{SIRM}$ ratio the contribution of ul- 
trafine magnetite grains $(\sim 20-30 \mathrm{~nm})$, and HIRM the presence of haematite (if the HIRM resists subsequent demagnetisation). Finally, having obtained multi-parameter magnetic data sets, two multivariate statistical methods can be applied to robustly characterize and/or differentiate the sediments; cluster analysis (using fuzzy c-means) and non-linear mapping, using one of the available programs (e.g. Vriend et al., 1988). Both techniques have been applied successfully to a number of environmental data sets (Maher et al., 2008).

\section{History of environmental magnetism in Greece}

Environmental sciences in general are quite well developed in Greece, focussing mainly on other research fields like chemistry, biology and meteorology. However, up to now, magnetic methods have not been thoroughly applied to pollution studies. Investigations performed by universities and national research institutes have identified and characterised a multiplicity of contaminated industrial sites. The relevant projects involve collection of historical data relating to a site, geological and hydrogeological data, chemical and physical measurements of soils or liquids (surface or groundwater, leachates etc). Contaminated sites are rather related to improper dumping of household and industrial wastes, than to mining areas and tailing ponds, to lignite-operating power plants and to petroleum refining and storage sites.

The first appearance of combined magnetic and geochemical data was through a $\mathrm{PhD}$ Thesis (Zeri, 1995) which, nevertheless, referred to polluted sites in the northwestern Meditterranean, followed by a pilot study at the Vouliagmeni Lake (Zeri et al., 1997) and an MSc Thesis (Tema, 2003). Finally, in the framework of a Joint Research and Technology Programme (2004-2006) between Greece and the United Kingdom, funded by the General Secretariat for Research and Technology of Greece and the British Council, the first integrated magnetic study towards pollution assessment was carried out. The project was entitled "Application of environmental magnetic techniques in detecting nanoparticle contamination". The research team comprised 3 groups: the first from the Aristotle University of Thessaloniki (Prof. D. Kondopoulou, Dr. A. Atzemoglou, Dr. I. Zananiri and Dr. S. Spassov, a visiting specialist from Belgium), the second from the University of Manchester (Prof. D. Polya, Dr. A. Gault) and last from the University of Lancaster (Prof. B. Maher, Dr. V. Karloukovski). The Greek research team had a strong background in rock magnetism and all the necessary experience to perform the required magnetic measurements, while the British research team had a long experience on environmental issues and especially heavy metal pollution. Moreover, they had all the necessary equipment and knowledge to perform geochemical measurements and additional and specialised magnetic experiments.

The target of this innovative, for Greece, project, that took into account the sparcity of similar works in the geographic region of Greece, was two-fold: (a) to investigate the interrelationship between susceptibility enhancement and elevated heavy metal concentrations and, thus, estimate the spatial distribution of several pollutants (b) to allow Greek scientists benefit from the long tradition of UK laboratories, pioneers in environmental magnetism, and acquire the know-how for the use of magnetic techniques towards pollution assessment; thus, dissemination of the results and the state-of-theart was a key issue that would constitute this discipline, nowadays increasingly applied by the Hellenic scientific community (e.g. Sarris et al., 2008), essential in environmental research.

Towards these scopes, three urban and suburban sites, with different pollution sources, were studied: the broader Kozani region, the old tanneries of Thessaloniki and a school yard, remediated former solid waste disposal site, at Potters Hill (UK). An overview of the results from the first two cases is presented, while the third case is still in progress. 

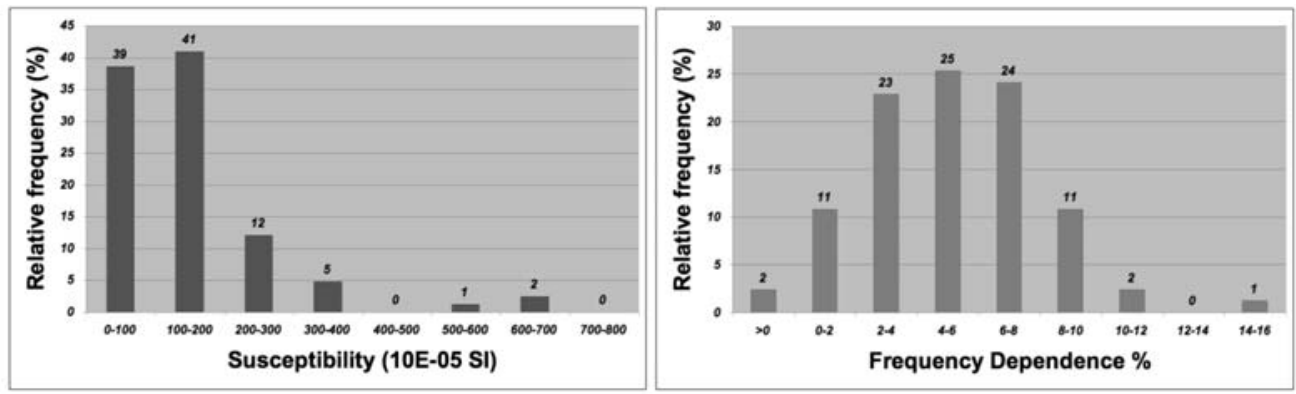

Fig. 3: Laboratory low-field magnetic susceptibility (left) and susceptibility frequency dependence (right) histograms.
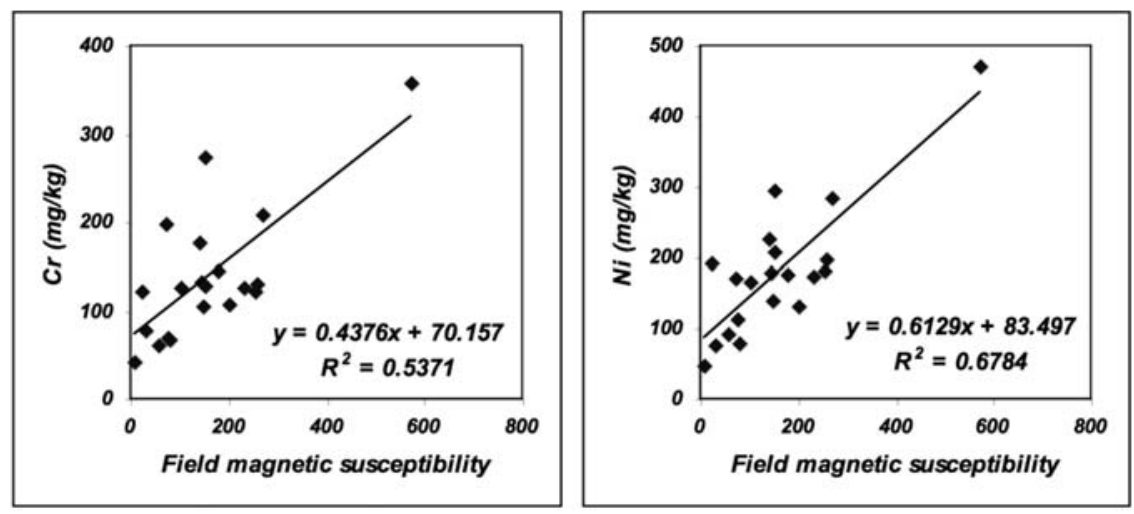

Fig. 4: Correlation of $\mathrm{Cr}$ and $\mathrm{Ni}$ in soils with corresponding field magnetic susceptibility values.

\subsection{The case of Kozani - flying ash pollution}

In the basin extending between Kozani and Ptolemaida four power plants are operating, on lignitic resources from that same basin. The target of the project carried out by Zananiri et al. (2006) was twofold: (a) to challenge the correlation between ferrimagnetic mineral content and geochemical properties of samples from polluted areas, (b) to estimate the spatial distribution of several pollutants within the study area. The main pollution source is flying ash from the emissions of the four power plants.

The magnetic susceptibility was mapped with a resolution of $1 \times 1 \mathrm{~km}$ and soil samples were collected from each grid point. The in situ susceptibility values exhibit significant variation, ranging from very low background values $\left(7 \times 10^{-5} \mathrm{SI}\right)$ to high values $\left(730 \times 10^{-5} \mathrm{SI}\right)$, with a mean of $140 \times 10^{-5}$ SI. The same variation arises from laboratory low and high frequency magnetic susceptibility, with a mean frequency dependence of 5\% (Fig. 3). Additional laboratory experiments were performed to determine the type and size of main magnetic carriers: isothermal remanence acquisition, stepwise alternating field demagnetisation of anhysteretic remanence magnetisation and hysteresis loops. The magnetic analyses were complemented by geochemical measurements and correlations between the various magnetic parameters and the concentration of specific pollutants were established (Fig. 4). A fair linear correlation was found between magnetic susceptibility, both field and laboratory measured, and the concentrations of soil $\mathrm{Cr}, \mathrm{Ni}$, and $\mathrm{Mn}$, whereas the correlation between magnetic susceptibility and concentration of $\mathrm{Zn}$ and $\mathrm{Cu}$ in soil was poor, suggesting that the pollutants are physically not related to the magnetic minerals. 


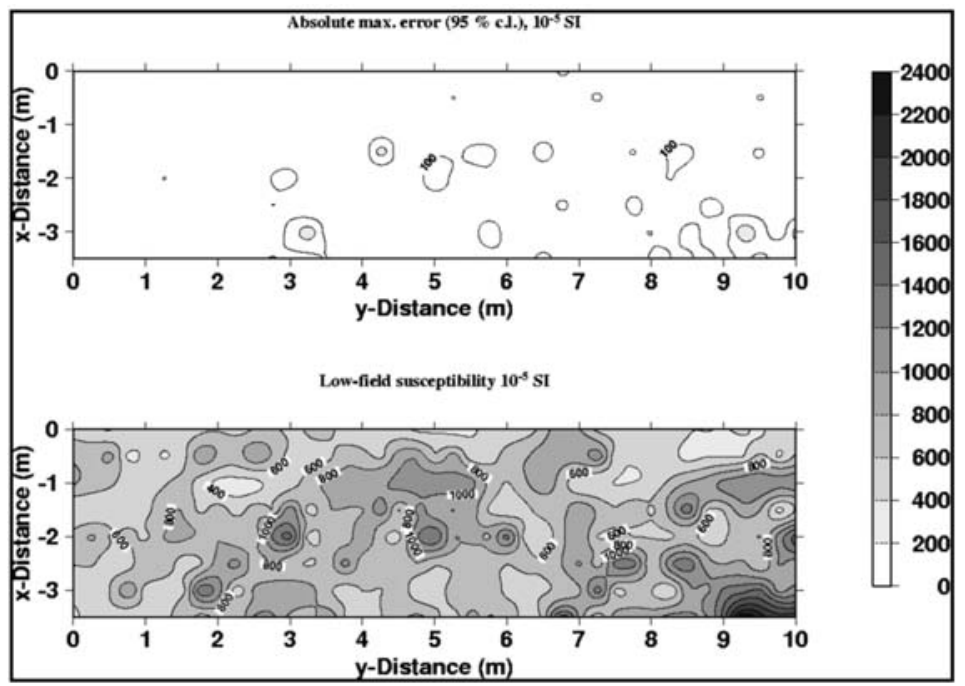

Fig. 5: Spatial distribution of susceptibility values (bottom), along with the corresponding absolute measurement errors (top).

\subsection{The case of the tanneries of Thessaloniki - heavy metal pollution}

The correlation between magnetic susceptibility and concentrations of key toxic components was tested (Spassov et al., 2004) at the highly polluted, nowadays closed, industrial area in Thessaloniki (Northern Greece), on which tanneries are situated inter alia. The tanneries of Thessaloniki constituted, from 1970 , the place of first industrial activity, but later on they were developed arbitrarily. Malodorous surface channels with polluted liquids, storage of dangerous chemical substances without precautions etc. resulted in the pollution of subsoil and underground waters and the progressive demission of the environment. The geological conditions in the region, as they were recorded by shallow drillings (Atzemoglou \& Skianis, 2003 and references therein) are unconsolidated sediments up to $5 \mathrm{~m}$ depth, consisting of sands, fluvial and torrential deposits and red clays with limestone conglomerates.

Relying on existing information, a grid was set up and high-resolution $(0.5 \times 0.25 \mathrm{~m})$ screening of magnetic susceptibility was performed. Soil samples were collected for rock magnetic and geochemical laboratory measurements at certain grid points (resolution of $0.5 \times 1.0 \mathrm{~m}$ ). For an assessment of the background signal sampling of unpolluted sites from the same soil type was also performed.

The susceptibility values may be divided in three categories: a) "background" values between 400 and $700 \times 10^{-5}$ SI spread over the whole area, b) local anomalies with values between 800 and $1000 \times 10^{-5}$ SI (Fig. 5, e.g. at $x=-1 \mathrm{~m}, \mathrm{y}=5 \mathrm{~m}$ ) and c) peak values $>1000 \times 10^{-5}$ SI measured at single points (Fig. 5 , e.g. at $x=-2 \mathrm{~m}, \mathrm{y}=3 \mathrm{~m}$ ). In order to normalize the field measurements we compared them with laboratory measurements performed on soil samples. We found that field values of $\sim 800 \times 10^{-5}$ SI correspond approximately to $400-450 \times 10^{-8} \mathrm{~m}^{3} / \mathrm{kg}$.

Preliminary magnetic measurements on dried and sieved $(<0.032 \mathrm{~mm})$ samples with intermediate susceptibility values indicate that $95 \%$ of the saturation isothermal remanent magnetization (SIRM) is acquired between 0 and $300 \mathrm{mT}$. The non-reversible temperature dependence of the low-field susceptibility exhibits a Hopkinson peak and is characterised by a considerable decrease near $580^{\circ} \mathrm{C}$. Above $580^{\circ} \mathrm{C}$ the susceptibility is nearly zero. These results indicate that the magnetic signal is car- 
ried by low-coercivity ferrimagnetic minerals, mainly magnetite with possible traces of iron sulfates. We did not find evidence for a high concentration of maghemite, which characterises fly ashes. Preliminary geochemical measurements indicated concentrations of $40-4000 \mathrm{mg}\left(\mathrm{Cr}^{3+}\right) / \mathrm{kg}$, 41-155 $\mathrm{mg}(\mathrm{Zn}) / \mathrm{kg}, 15-35 \mathrm{mg}(\mathrm{As}) / \mathrm{kg}$ and 0-65 (Dichloronethane)/kg in soils.

\section{Conclusions}

The application of enviromagnetic techniques is based on the fact that human activities, like fossil fuel combustion, waste incineration, metal smelting and working, produce considerable amounts of iron minerals, easily detected by field and laboratory measurements of magnetic properties. Thus, they constitute an innovative, non-evasive, rapid and cost-effective method for tracing and quantifying nanoparticle pollution. However, it is important to point out that magnetic techniques do not substitute geochemical measurements, since a general numeric magnetic susceptibility - pollutant concentration relationship has not yet been established, but they can contribute significantly to an optimum geochemical survey planning by defining areas of increased interest and thus cut down excavation cost and time.

The discipline of environmental magnetism for the assessment of pollution distribution and its sources is highly prominent worldwide and during the past few years is being developed in Greece as well. The Aristotle University of Thessaloniki, in the framework of a bilateral cooperation between Greece and the UK, implemented magnetic environmental research in several areas with different pollution sources. From the realization of this project, important conclusions for the specific areas were drawn and the method know-how was acquired by Greek researchers. In particular:

- The topsoil studied in the vicinity of the lignite-bearing power plants in the Kozani-Ptolemaida basin was characterized by significant variation, reaching high values, and the increased magnetic susceptibility is due to the presence of anthropogenic magnetic particles contained in industrial dust and fly ashes.

- Magnetic susceptibility values, remarkably above background, were detected in the tanneries of Thessaloniki, indicating high concentrations of heavy metals. This conclusion was verified by complementary geochemical measurements and attributed to influx of liquid and waste pollutants that resulted from leather manufacturing.

\section{Acknowledgements}

The case studies discussed in Sections 3.1 and 3.2, were funded by the General Secretariat of Research \& Technology and the British Council.

\section{References}

Apblett,A.W., Al-Fadul, S.M., Chehbouni, M. \& Trad, T., 2001. Removal of Petrochemicals from Water Using Magnetic Filtration. Proceedings of the $8^{\text {th }}$ International Environmental Petroleum Consortium.

Atzemoglou, A. \& Skianis, G., 2003. Geophysical investigation in Thessaloniki tanneries in the framework of NORISC project, Internal report of the Institute of Geology and Mineral Exploration, pp. 20.

Cornell, R.M. \& Schwertmann, U., 1996. The Iron Oxides, VCH, Weinheim, Germany, pp. 703.

Dearing, J.A., Hay, K.L., Baban, S.M.J., Huddleston, A.S., Wellington, E.M.H. \& Loveland P.J. 1996. Magnetic susceptibility of soil: an evaluation of conflicting theories using national data set, Geophysical Journal International, 127, 728-734. 
Diabaté, S., Mülhopt, S., Paur, H.R., Wottrich, R. \& Krug, H.F., 2002. In vitro effects in incinerator fly ash on pulmonary macorphages and epithelial cells, International Journal of Hygiene and Environmental Health, 204, 323-326.

Evans, M.E. \& Heller, F., 2003. Environmental Magnetism - Principles and Applications of Enviromagnetics. Academic Press, pp. 299.

Ferguson, C.C., 1999. Assessing Risks from Contaminated Sites: Policy and Practice in 16 European Countries, Land Contamination \& Reclamation, 7 (2), 33.

Hanesch, M., Scholger, R. \& Rey, D., 2003. Mapping distribution around an industrial site by measuring magnetic parameters of tree leaves, Atmospheric Environment, 37, 5125-5133.

Hannam, J. \& Heller, F., 2001. Magnetic investigation of roadside leaves in Zürich, Switzerland, Environmental Magnetism Network MAGazine, 04.

Heldstab, J. 2002, PM10-Emissionen des Verkehrs, Statusbericht Teil Schienenverkehr, Umwelt-Materialien, №144, Luft, Bundesamt für Umwelt, Wald und Landschaft (ed.), Bern, pp. 48 [in German with English abridgement].

Maher, B.A. \& Thompson, R., 1999. Quaternary Climates, Environments and Magnetism. Cambridge University Press, pp. 390.

Maher, B.A., Watkins, S.J., Brunskill, G., Alexander, J. \& Fielding, C.R., 2008. Sediment provenance in a tropical fluvial and marine context by magnetic 'fingerprinting' of transportable sand fractions, Sedimentology, DOI 10.1111/j.1365-3091.2008.00999.x.

Petrovsky, E., Kapička, A., Zapletal, K., Šebestová, E., Spanilá, T., Dekkers, M.J. \& Rochette, P., 1998. Correlation between magnetic parameters and chemical composition of lake sediments from Northern Bohemia - Preliminary study, Phys. Chem. Earth, 23 (9-10), 1123-1126.

Sarris, A., Kokinou, E., Aidona, E., Kallithrakas-Kontos, N., Koulouridakis, P., Kakoulaki, G., Droulia, K. \& Damianovits, O., 2008. Environmental study for pollution in the area of Megalopolis power plant (Peloponnesos, Greece), Environ. Earth Sc., DOI 10.1007/s00254-008-1676-3.

Shukla, A., Timblin, C., BeruBe, K., Gordon, T., McKinney, W., Driscoll, K., Vacek, P. \& Mossman, B.T., 2000. Inhaled particulate matter causes expression of nuclear factor (NF)- $\square$ B-related genes and oxidant dependent NF- $x \mathrm{~B}$ activation in vitro. American Journal of Respiratory Cell and Molecular Biology, 23, 182-187.

Smith, K.R., Veranth, J.M., Hu, A.A., Lighty, J.S.\& Aust, A.E., 2000. Interleukin-8 levels in human lung epithelial cells are increased in response to coal fly ash and vary with the bioavailability of iron as a function of particle size and source of coal. Chemical Research in Toxicology, 13, 118-125.

Spassov, S., Zananiri, I., Kondopoulou, D., Atzemoglou, A., Polya, D., Maher, B., Egli, R. \& Heller, F., 2004. Application of environmental techniques in detecting nanoparticle contamination, Contribution to Geophysics and Geodesy, Vol. 34, Special Issue, 141-143.

Tema, E., 2003. Application of magnetic methods on the investigation of the environmental conditions on lake sediments. A case study: Koumoundourou Lake and Kerkini Lake. Master Thesis, Aristotle University of Thessaloniki, pp. 113.

von Blottnitz, H. 2006. A comparison of air emissions of thermal power plants in South Africa and $15 \mathrm{Eu}-$ ropean countries, Journal of Energy in Southern Africa, 17, 72-81.

van Maanen, J.M.S., Borm, P.J.A., Knaapen, A., van Herwijnen, M., Schildermann, P.A.E.L., Smith, K.R., Aust, A.E. \& Tomatis, M. 1999. In vitro effects of coal fly ashes: Hydoxyl radical generation, iron release, and DNA damage and toxicity in rat lung epithelial cells, Inhalation Toxicology, 11, 1123- 1141.

Vriend, S.P., van Gaans, P.F.M., Middelburg, J. \& de Nijs, A., 1988. The application of fuzzy c-means 
analysis and non-linear mapping to geochemical datasets: examples from Portugal, Appl. Geochem., 3, 213-224.

Verosub, K.L. \& Roberts, A.P., 1995. Environmental magnetism: Past, present and future. Journal of Geophysical Research, 100 (B2), 2175-2192.

Walden, J., Oldfield, F. \& Smith, J., 1999. Environmental Magnetism: A practical Guide. Quaternary Research Association, pp. 243.

Watson, J.H.P., Ellwood, D.C., Deng, Q.X., Mikalovsky, S., Hayter, C.E. \& Evans, J., 1995. Heavy metal adsorption on bacterially produced FeS. Minerals Engineering, 8, 1097-1108.

Watson, J.H.P., Croudace, I.W., Warwick, P.E., James, P.A.B., Charnock, J.M. \& Ellwood, D.C., 2001. Adsorption radioactive metals by strongly magnetic iron sulfide nanoparticles produced by sulfatereducing bacteria. Separation Science and Technology, 36, 2571-2607.

Zananiri, I., Kondopoulou, D., Gault, A., Atzemoglou, A., Polya, D., Maher, B. \& Spassov, S., 2006, Application of magnetic properties of nanoparticles in detecting pollution: Theory and a case study from Kozani region, NW Greece, Travaux Géophysiques, XXVII, $10^{\text {th }}$ Castle Meeting on New Trends in Geomagnetism Abstracts, 128.

Zeri, Ch., 1995. Application of the magnetic methodology in open marine systems. The case of NW Mediterranean, PhD Thesis, University Athens, pp. 142.

Zeri, Ch., Chroneou, A. \& Scoullos, M., 1997. Geochemical observations and magnetic characteristics of the Vouliagmeni Lake, Proceedings of the $5^{\text {th }}$ Hellenic Symposium of Oceanography and Fishery, Vol. II, 333-336.

Zevenhoven, R. \& Kilpinen, P., 2001. Control of Pollutants in Flue Gases and Fuel Gases. TKK, Espoo 2001 .

Zhang, C.X., Huang, B.C., Li, Z.Y. \& Liu, H., 2006. Magnetic properties of highroad-side pine tree leaves in Beijing and their environmental significance, Chin. Sci. Bull., 51 (24), 3041-3052. 